\section{UNIVERSITY \\ of DEBRECEN \\ FACULTY OF \\ HEALTH}

NYÍREGYHÁZA

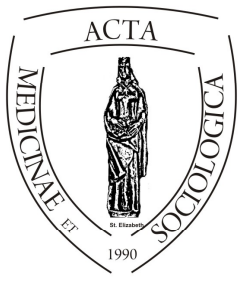

ACTA

MedSoc

VOLUME 5.

2014

\title{
A foglalkoztatás jellemzői Nyíregyházán
}

\author{
R. Fedor Anita - Jávorné Erdei Renáta \\ Debreceni Egyetem, Egészségügyi Kar
}

\begin{abstract}
Characteristics of employment in Nyíregyháza. Our present article aims to describe the characteristics of the economic activities of the residents in Nyíregyháza. The basis of our work is 'Háztartáspanel' of 2008., 2010. and 2012., which makes it possible to conduct a comparative analysis of the relevant data. Within the topic of economic activity our study deals with the description of local employment and unemployment tendencies and their background aspects in greater detail. Also, they are discussed in both a regional and an international context.

The favourable tendency regarding the employment rate is indicated in national, regional, county as well as town data. According to Nyíregyháza data, the growth in employment as compared to 2008 is $2,2 \%$ and $2,6 \%$ as compared to 2010 . City employment data of 2008, 2010 and 2012 show no significant change in the employment statistics for women. However, 2012 data show a certain growth in working opportunities for men. This change is significant (4\% and 6\%) as compared to 2008 and 2010.

Level of school education significantly influences work opportunities. This causeresult relationship is obviously indicated by the data of Nyíregyháza as well.
\end{abstract}

Key words: employment rate, unemployment rate, school education, regional context

DOI: $10.19055 / \mathrm{ams} .2014 .5 / 12-13 / 3$ 


\section{Bevezetés}

A népesség foglalkoztatási helyzete, munkanélkülivé válása, a munka nélkül eltöltött idő tartama messzemenően meghatározza az érintettek jövedelmi viszonyait, életkörülményeit.

Jelen írásunkban Nyíregyháza város lakói gazdasági aktivitásának jellemzőit mutatjuk be. Elemző munkánk alapját a 2008., 2010. és 2012. évi Háztartáspanel felvételek adják, melyek lehetővé teszik a vonatkozó adatok, munkaerő-piaci jellemzők összehasonlító vizsgálatát. Tanulmányunkban a gazdasági aktivitás témáján belül részletesen foglalkozunk a helyi foglalkoztatási, munkanélküliségi tendenciák bemutatásával, ezek háttértényezőinek elemzésével, melyet nemzetközi és regionális kontextusban is értelmezünk. Jelen tanulmánykötet további írásai más és más nézőpontból vizsgálják az adott város lakóinak életminőségét: Jávorné, R. Fedor és Berencsiné (2014) a nyíregyházi lakosok szubjektív egészségi állapotára vonatkozó adatokat elemzik, Balogh és R. Fedor (2014) a segélyezés hatékonyságára vonatkozóan tesznek megállapításokat.

Munkánk fókuszában a 2012. évi adatfelvétel gazdasági aktivitásra vonatkozó adatainak elemzése mellett, az aktuális tendenciák és a korábbi, 2008-as és 2010-es adatfelvételek eredményeivel történő összevetés áll. Ebből adódóan a foglalkoztatási és munkanélküliségi helyzetkép felvázolásában különböző tényezők mellett, kitüntetett figyelmet szentelünk a megszerzett iskolai végzettségnek, mint magyarázó változónak. E tekintetben arra koncentrálunk, hogy az iskolázottsági szint kedvezőbb volta felfogható-e továbbra is a munkanélküliség elleni egyfajta védőfaktorként.

\section{Általános helyzetkép}

Hazánk foglalkoztatási mutatói alul maradnak az Európai Unió átlagához képest, azonban a 2008-as adatokhoz viszonyítva relatív helyzetünk pozitív irányba mozdult. Ennek oka, hogy a magyarországi foglalkoztatottak száma bővült 2008 és 2012 között (különösen igaz ez 2010-hez viszonyítva), míg az EU mutatóit rontotta a krízishelyzetbe került tagállamok - elsősorban Spanyolország és Görögország - foglalkoztatási helyzete. A 8\%-os különbség azonban még így is jelentősnek mondható (KSH 2012).

Magyarországon a 15-64 éves korú népességre vonatkoztatott foglalkoztatási ráta 57,2\%-os volt 2012-ben, mely közel 3\%-kal magasabb a két évvel korábban mérthez (2010:54,5\%), s közel azonos a pénzügyi válság hatására kialakult 
2008-as gazdasági válság idejének foglalkoztatottsági mutatójával (56,7\%) (KSH 2012).

A régiók szerinti foglalkoztatási arányok az Észak-Alföld, KözépMagyarország és Nyugat-Dunántúl tekintetében alakultak a legkedvezőbben a vizsgálat évében (2012) az egy évvel korábbi mutatókhoz viszonyítva. A kedvező tendencia régiónként változóan 2,3-3\%-os növekedésben érhető tetten, szemben Észak-Magyarországgal és Közép-Dunántúllal, ahol a foglalkoztatottsági szint nem érte el az egy évvel korábbit (KSH 2012). A megyénkénti foglalkoztatási helyzet alakulásában részben visszaköszönnek a fentebb említett regionális jellemzők, hiszen a foglalkoztatás emelkedése két gazdaságilag kedvezőtlenebb helyzetü megyében - Szabolcs-Szatmár-Beregben és Nógrádban volt a legjelentősebb. Mindez annak a következménye, hogy a gazdasági válság negatív hatásai a gazdaságilag fejlettebb megyéket - elsősorban az ország nyugati-, észak- nyugati területein elhelyezkedő megyéket - érintette hátrányosan, ugyanis a válság hatására megvalósult létszámleépítés föként a gépiparban és építőiparban dolgozókat érintette leginkább. Noha a leghátrányosabb helyzetú megyék közül az előbb említett kettő esetében a korábbi különbségek mérséklődtek, Szabolcs-Szatmár-Bereg megye foglalkoztatási és munkanélküliségi rátája még mindig sokkal kedvezőtlenebb az országos átlaghoz viszonyítva. A rendszerváltozás óta a legkedvezőtlenebb foglalkoztatási mutatókkal bíró megyék közé tartozik változatlanul, Szabolcs-Szatmár-Bereg megye, Borsod-Abaúj Zemplén és Nógrád megye.

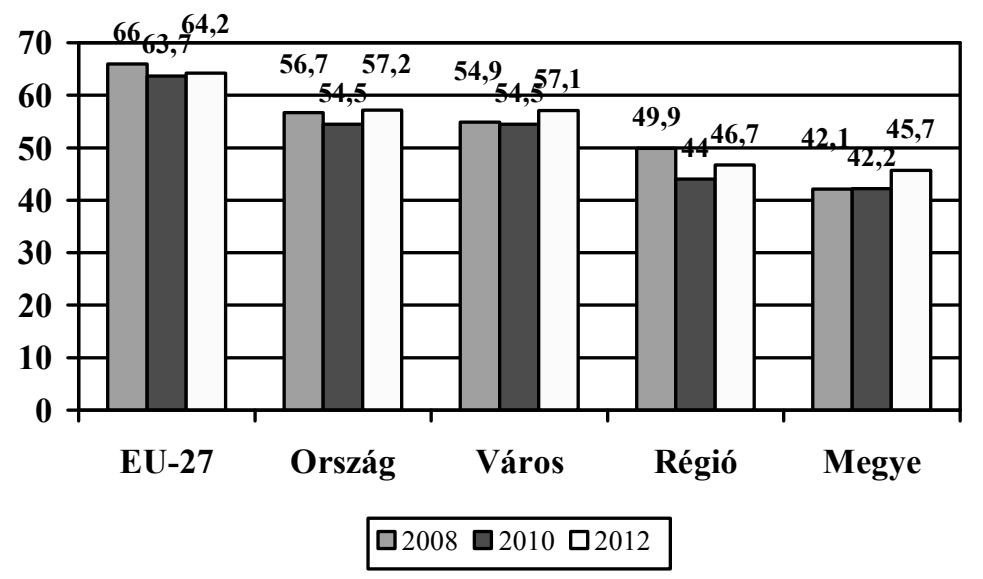

1. számú ábra. A foglalkoztatottság aránya $(\%)^{1}$.

Forrás: Eurostat 2012; KSH 2012; R. Fedor 2012; Fábián 2008.

\footnotetext{
${ }^{1}$ Kutatásunk módszertanilag különbözik a KSH által végzett munkaerő felméréstől. Ott a 15 - 74, illetve 15 - 64 év közötti korosztályokra vetítve mérik a foglalkoztatottságot, a nyíregyházi kutatás mintájába pedig eleve a 18 éves és annál idősebbek kerülhettek be.
} 
A foglalkoztatottak számában megnyilvánuló kedvező tendencia az országos, regionális, megyei jellemzők mellett a városi adatokban is megmutatkozik, legalábbis a 2010-ben mért szinthez képest.

Nyíregyháza város lakóit érintő kutatásunkban, arra a kérdésre, hogy „,Dolgozik-e Ön jelenleg" a válaszadók 54,9 százaléka válaszolt igennel 2008-ban, $54,5 \%$ 2010-ben, 2012-ben pedig 57,1\%. A foglalkoztatottak bővülésének mértéke így 2008-hoz viszonyítva 2,2\%, míg 2010-hez hasonlítva 2,6\%. Az 1. számú ábra adatai alapján megállapíthatjuk, hogy az Észak-alföldi régió és Szabolcs-Szatmár-Bereg megye foglakoztatási rátája szinte egybeesik, azonban a városi mutató csaknem azonos az országos átlaggal. Ennek oka, hogy a megyei átlagot nagymértékben alakítják a kedvezőtlen helyzetű települések jóval átlag alatti értékei, ott a munkaerő-piaci nehézségek jelenleg is számottevőek, míg Nyíregyháza, mint a megye székhelye vélhetően kedvezőbb elhelyezkedési lehetőséget biztosít a városban élők számára.

\section{A foglalkoztatottság nemenkénti eltérései}

Hazánkra és az Európai Unió tagállamainak meghatározó részére jellemző a foglalkoztatottság nemek szerinti eltérése. Az Európai Unió átlagos mutatóit vizsgálva azt látjuk, hogy a nők és férfiak foglakoztatási rátája között különbség állandósult, mindhárom vizsgált évben több mint $10 \%$-os rés tapasztalható. Magyarország tekintetében a helyzet hasonló, azzal a különbséggel, hogy mindkét nem esetében jelentős lemaradást könyvelhetünk el az Európai Unió átlagához képest. Ennek oka a hazai munkaerö-piaci nehézségek globális jellege, mindemellett a hazai női foglalkoztatás mérsékelt arányáért a gyermeket nevelő nők alacsony aktivitási rátája a felelős. Mivel az ok-okozati viszonyokat a 2010-es elemző munkánkban részletesen kifejtettük ${ }^{2}$, ezért jelen írásunkban csak érintjük e kérdést.

\footnotetext{
${ }^{2}$ A hivatkozott anyag elérhető az Acta Medicinae et Sociologica folyóirat különszámában: R. Fedor Anita (2012): A gazdasági aktivitás lokális jellemzői. Nők és férfiak a „munka piacán”. In: Fábián Gergely - Patyán László - Huszti Éva (szerk.): Életminőség Nyíregyházán., Nyíregyháza, 83-98.
} 


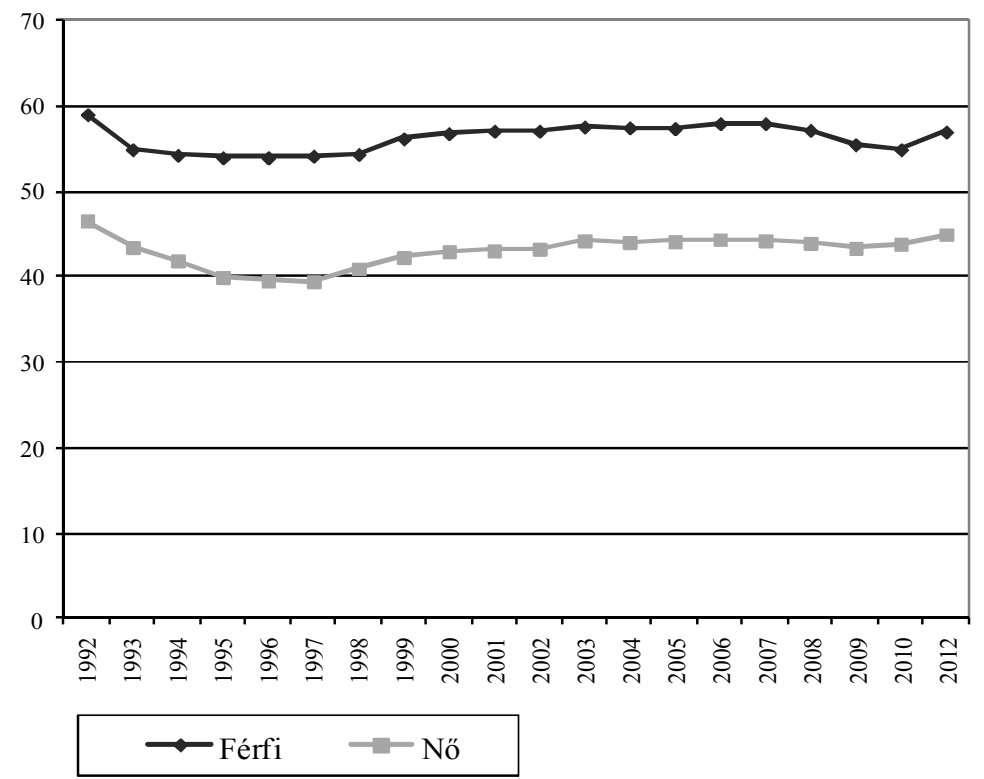

2. számú ábra. A foglalkoztatási ráta alakulása nemenként a 15-74 évesek körében, 1992-2012.

Forrás: KSH 2012.

A foglalkoztatottak nemenkénti megoszlását vizsgálva látható, hogy a férfiak aránya minden évben magasabb (2009-ben a foglalkoztatottak 54,1\%-a férfi), azonban a Munkaerő-felmérés (MEF) adataiból az is kiderül, hogy a válság negatív hatása a férfiakat jobban érintette, mint a nőket (KSH 2012). Ez azzal függ össze, hogy a munkaerőpiacot elérő recesszió a föként férfiakat alkalmazó ágazatokban (feldolgozóipar, gépipar, építőipar) volt jelentős. Ennek köszönhetően a férfiak foglalkoztatási mutatóiban tapasztalható nagyobb változás. Míg a nők foglalkoztatási rátája 2008 és 2009 között 0,6\%-kal, majd 2010-re további 0,1\%kal, addig a férfiaké a hasonló időszakban 1,7\%-, és 0,6\%-kal esett vissza. 2012re a válság hatásai enyhültek, melynek eredményeként mind a nők, mind a férfiak foglalkoztatási rátája nőtt, előbbi csoport esetében 1\%-kal, utóbbiak tekintetében 2\%-kal. Ennek ellenére a foglalkoztatási esélyek egyenlőtlensége továbbra is jelentős. Régiónkénti bontásban a nők foglalkoztatási rátája KözépMagyarországon volt a legkedvezőbb (50,0\%), addig a rangsorban az utolsó pozíció Észak- Magyarországé (38,5\%) lett. Az Észak-Alföldön élő nők helyzete 
valamelyest javult, hiszen 2010-ben még ez a régió tudhatta magáénak az utolsó helyet, azonban 2012-re a 40,8\%-os női foglakoztatási rátával egy hellyel előbbre került (KSH 2012). Régiónk foglalkoztatottsági adatainak nemenkénti megoszlását az országos átlaghoz viszonyítva megállapítható, hogy lemaradásunk a fentebb említett kedvező változások ellenére is számottevő. A férfiak rátája 7\%kal, a nőké 4\%-kal marad el a hazai átlagtól.

A gyermekkel rendelkező nők foglalkoztatásának számos meghatározója van. A családban nevelkedő gyerekek száma, életkora, az édesanya iskolai végzettsége, a lakóhely típusa köztudottan befolyásolja az elhelyezkedési lehetőségeket. Ebben az esetben az anyák iskolai végzettségét, mint magyarázó változót vizsgáljuk, elhelyezkedésük tükrében. A nyolc osztállyal sem rendelkező anyák munkaerö-piaci szerepvállalása szinte lehetetlen. Eredendően rossz helyzetük nem változott 1990-1996 és a 2005-2008 közötti időszakban, azonban a további iskolai végzettség kategóriák mindegyikében negatív irányú elmozdulás tapasztalható. Meglehetősen magas a diplomával rendelkezők foglalkoztatásában bekövetkezett változás (Ferge 2010). (3. számú ábra)

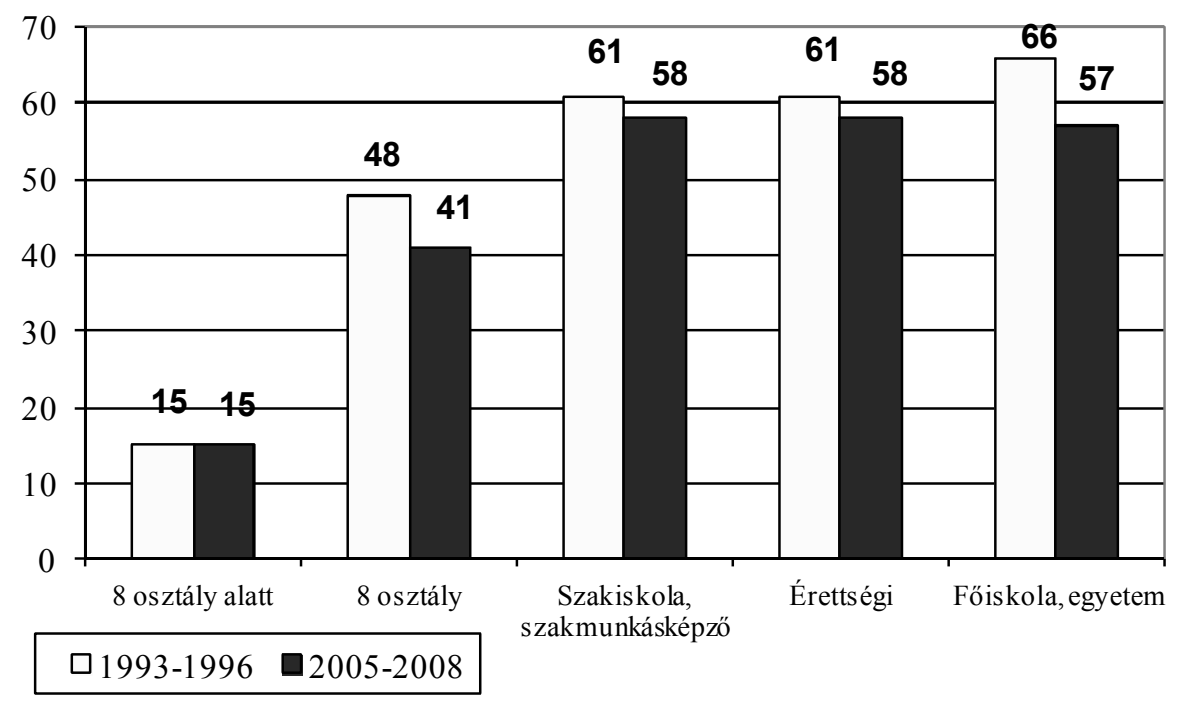

3. számú ábra. A fizetett munkát végző anyák aránya iskolai végzettség szerint (\%).

Forrás: Ferge 2010.

A munkavállalás nehézségeit a harmadik gyermek jelenléte tovább erősíti. A három és többgyermekes édesanyák foglalkoztatási rátája közötti különbség igen markáns, $\mathrm{s}$ a két vizsgált időintervallumban hátrányuk tovább fokozódott. Míg 
1993-1996 között egyharmaduk kereső volt, addig 2005-2008 között részesedésük egynegyednyire csökkent. Az egy és kétgyermekes anyák foglalkoztatása nem tér el, 63-62\%-uk végzett fizetett munkát a korábbi időszakban, melyben bár megfigyelhető némi lefelé irányuló elmozdulás (2-4\%) 2005-2008 között, azonban ez sokkal mérsékeltebb, mint a három és többgyermekesek esetén (Ferge 2010). A kisgyermeket nevelő nők foglalkoztatási mutatói igen kedvezőtlenek nemzetközi összehasonlításban is. Ennek oka, hogy az akár három évig gyermekgondozási szabadságon lévő anyák inaktívnak minősülnek, s egy adott évben a munkavállalási korú nők 10\%-át érinti (KSH 2010).

A nyíregyházi adatfelvétel válaszadói között 669 nő és 506 férfi volt. A „Dolgozik-e Ön jelenleg” kérdésre a nők 54\%-a válaszolt igennel, míg a férfiaknál ez az arány 65\% volt. A nagyságrendbeli eltérések (11\%) az országosan mért különbségeknek megfelelően alakul a helyi foglalkoztatási adatok nemenkénti megoszlásában. Azonban a tényleges százalékos megoszlások a nyíregyházi nők és férfiak kedvezőbb munkaerö-piaci helyzetéröl árulkodnak, hiszen a nők $45 \%$-os és a férfiak $57 \%$-os foglalkoztatási rátájának országos átlagát a helyi nők és férfiak foglalkoztatási mutatói 8-8\%-kal haladják meg. Ennek magyarázatát a már korábban említett „megyeszékhely pozícióból” adódó kedvező körülményeknek tulajdonítjuk.

Az idősoros $(2008,2010,2012)$ városi adatokra irányítva a figyelmet megállapíthatjuk, hogy a nők körében gyakorlatilag nem mérhető változás, a férfiak körében 2008 és 2010 között csökkenés mutatkozott (közel 2\%-os), ami megfelel az országos tendenciáknak. Ez nemcsak helyi szinten, de országosan is elsősorban azzal magyarázható, hogy a gazdasági válság hatására bekövetkező leépítési hullám a férfiakat érintette erőteljesebben. A 2012-es adatokban a férfiak munkavállalási lehetőségeinek bővülése figyelhető meg, mely jelentősnek mondható mértékben (4\% és 6\%) nőtt 2008-hoz és 2010-hez képest. 


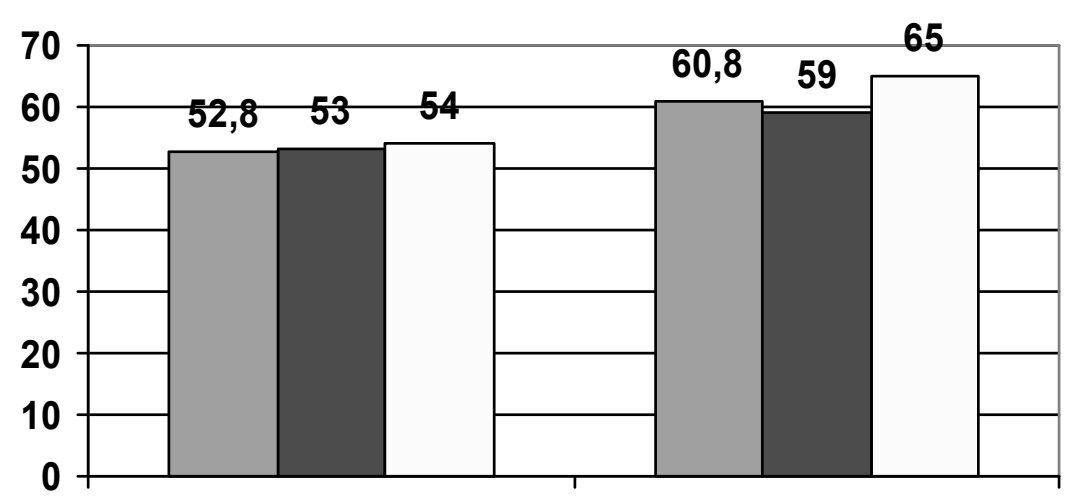

Nök

Férfiak

$\square 2008 \square 2010 \square 2102$

4. számú ábra

A foglalkoztatottság aránya nemek szerint Nyíregyházán 2008, 2010, 2012 (\%).

Forrás: Fábián 2008; Háztartáspanel felvétel 2010, 2012.

\section{Az iskolai végzettség és foglalkoztatottság összefüggései}

Az emberi töke elmélet szerint, az egyén az oktatásba, képzésbe történő bekapcsolódását egyfajta beruházásként értelmezi, melynek költségei ettől eltérő időpontban a munkaerőpiacon térülnek meg (Varga 1998). Az emberi tőke fejlesztésére irányuló befektetés és megtérülés viszonyának vizsgálata a közgazdaságtanban mikroökonómiai alapokon nyugszik, a szociológiai aspektus a státusmegszerzési modellek gyakorlatát követi. A két megközelítés közötti alapvetö különbség, hogy míg a közgazdaságtan a befektetés/megtérülés viszonyát objektív mérce, materiális keretek mentén vizsgálja, addig a szociológiában az egyén szubjektív elégedettségi mutatói is megjelennek, mint magyarázó változók. Az iskolai végzettség gyengülő munkaerő-piaci esélyeket előrejelző hatásáról számolnak be a legutóbbi státuszmegszerzési vizsgálatok (Altorjai és Róbert 2006). Bár, a diplomával rendelkezők aktivitási rátája magasabb, mint az alacsonyabb iskolai végzettségü csoportoké, 2000 óta esetükben is visszaesés tapasztalható (Scharle 2008). 


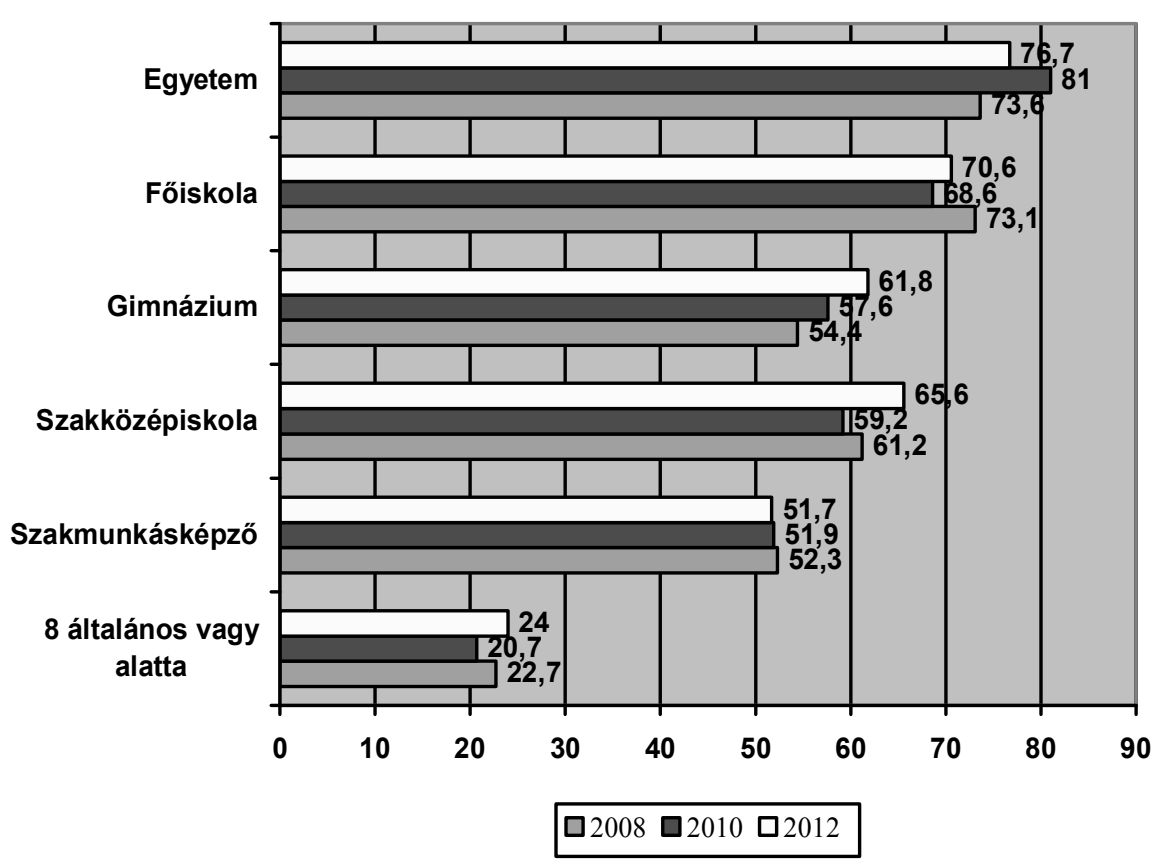

5. számú ábra. Foglalkoztatottsági arányok az iskolai végzettség függvényében, Nyíregyházán 2008, 2010, 2012 (\%).

Forrás: Fábián 2008, Háztartáspanel felvétel 2010, 2012.

Az iskolai végzettség szintje jelentősen meghatározza az elhelyezkedési lehetőségeket. Ezt az ok-okozati összefüggést a nyíregyházi adatok is egyértelmüen tükrözik. Az 5. számú ábrából a megszerzett iskolai végzettség és a foglalkoztatási mutatók milyensége egyfajta szinkronitást mutat, a magasabban kvalifikált csoportok munkavállalási lehetőségei nagyságrendekkel kedvezőbbek.

2008 és 2012 között Nyíregyházán a szakmunkás bizonyítvánnyal rendelkező foglalkoztatottak aránya szinte változatlan, esetükben az aktuális iskolai végzettség elhelyezkedésre gyakorolt hatása stabilnak mondható, mindhárom évben a megkérdezettek megközelítőleg 52\%-a dolgozott. Folyamatos emelkedés tapasztalható a gimnáziumi érettségivel rendelkezők körében, esetükben 2008 és 2012 között több mint 7\%-kal nőtt a foglalkoztatottak aránya. A többi iskolai végzettségi csoportban a folyamatok változásai vegyes képet mutatnak. A legfeljebb nyolc osztályt végzettek helyzete kedvezőtlen irányba fordult 2008 és 2010 között, azonban két évvel később növekedés tapasztalható, mely mértékét tekintve meghaladta a 2010-es csökkenést. A legnagyobb elmozdulás a középiskolát végzettek csoportján belül tapasztalható, hiszen a növekedés, közel 6,5\%-os 
volt 2010 és 2012 között, a munkát végzők aránya meghaladta a 2008-as szintet. A diplomások eltérő folyamatokkal jellemezhetők. Míg 2008-ban mindkét vizsgált csoport foglalkoztatási mutatója 73\% volt, addig 2010-ben már a lehetőségek bővülése és szükülése egyszerre érintette a magasan kvalifikáltak körét. A föiskolai diplomával rendelkezők az utóbbi csoportot testesítik meg, a csökkenés 4,5\%-os volt körükben, azonban két évvel később enyhe növekedés hatására a fizetett munkát végzők aránya közelített a négy évvel korábbi értékhez. Az egyetemet végzettek igen kedvező helyzete 2010-re tovább javult, a 7\%-os növekedés kiugróan magasnak tekinthetö, föleg ha figyelembe vesszük, hogy a többi iskolai végzettségü csoport szinte mindegyikében csökkent a foglalkoztatottak aránya ebben az időintervallumban. A legmagasabban kvalifikáltak munkaeröpiaci helyzete 2012-re kedvezőtlenül módosult, több mint 4\%-kal visszaesett. Összességében megállapítható, hogy a foglalkoztatottak arányában megfigyelhető változás nyomán végigkísérhető a 2008 -as pénzügyi válság negatív hatása (kivéve az egyetemi végzettséggel rendelkezők), majd a 2012-es adatok a foglalkoztatási viszonyok visszarendeződéséről árulkodnak. Mindemellett a legalacsonyabb végzettségúek foglalkoztatottakon belüli súlya elenyésző, hasonlóan az országosan mért adatokhoz.

Utóbbi megállapításunk nemzetközi összehasonlításban is helytálló. A 6. számú ábra szerint a 25-64 éves korosztály iskolai végzettség szerinti foglalkoztatási rátájában a felsőfokú végzettségúek egyértelmủ előnye rajzolódik ki mind hazai, mind Európai Uniós vonatkozásban. Hazai viszonylatban az ez alatti iskolai végzettségüek foglalkoztatási rátái jelentősen elmaradnak a felsőfokú végzettségüekétől, a közösségi adatok közötti rés sokkal mérsékeltebb. Hasonló összefüggések figyelhetők meg a közép-, és felsőfok esetében. 


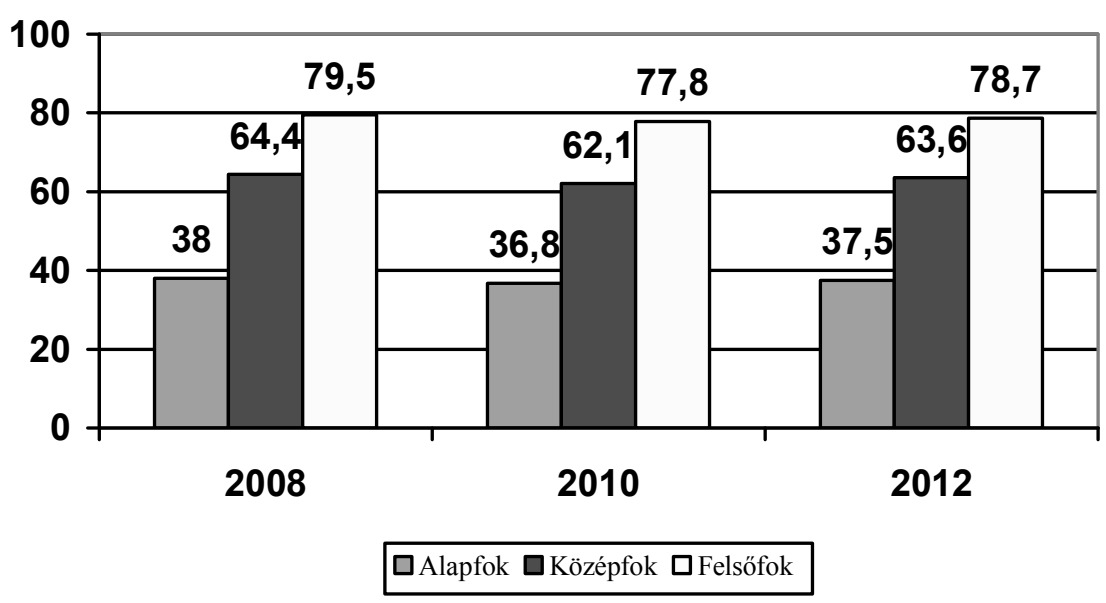

6. számú ábra.

Foglalkoztatási ráta az iskolai végzettség függvényében Magyarország (25-64 évesek). Forrás: Eurostat.

Összességében megállapítható, hogy a magas iskolai végzettséggel rendelkezők munkaeró-piaci helyzete az Európai Unióban és hazánkban is hasonlóan kedvezőnek tekinthető, az unió előnye egyik évben sem számottevő. Az eltérések növekedése középfokon figyelhető meg. Ebben az esetben az Európai Unió tagállamainak átlaga 7-8\%-kal is magasabb, mint itthon. A legszembetűnőbb, s talán behozhatatlan különbséget a legalacsonyabb iskolai végzettségü fokozatban tapasztalhatjuk, itt a közösségi és hazai átlag közötti eltérés minden évben 15,0$18,5 \%$ az Európai Uniós átlag javára. 


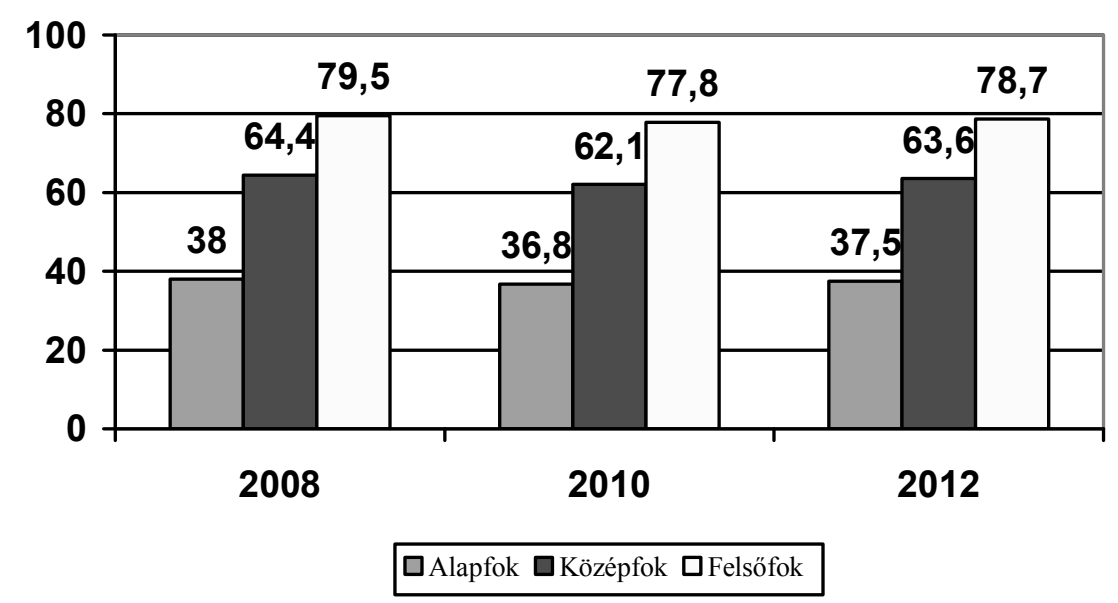

7. számú ábra. Foglalkoztatási ráta az iskolai végzettség függvényében EU 27 (25-64 évesek).

Forrás: Eurostat.

A tanulási, képzési lehetőségbe történő bekapcsolódásnak számos oka lehet. Mindamellett, hogy további képességek és készségek megszerzését biztosítja, egyúttal a választás lehetőségét is kínálhatja az egyén számára. A képzésbe való bekapcsolódás eszköze lehet a későbbi pályamódosításnak, a munkahely változtatás pedig Rosen (1998) szerint, az ember tőke felhalmozásának egyik formája. A tanulásba való bekapcsolódás további hozama lehet a jövedelememelkedés. A „Folytat-e Ön jelenleg tanulmányokat” kérdésre válaszolók 7\%-a válaszolt igennel, 2,5-szer több nő, mint férfi. Az iskolai végzettség függvényében azt tapasztalhatjuk, hogy ezen belül a legnagyobb csoportot azok alkotják, akik gimnáziumi érettségivel, illetve egyetemi diplomával rendelkeznek. A jelenleg képzésben részt vevők háromnegyede munka mellett tanul. A választott képzések palettája igen bö, többen idegen nyelvet tanulnak, OKJ képzésben vesznek részt, további diploma megszerzésére törekszenek.

\section{A foglalkoztatás szektorális jellege, foglalkoztatási forma, munka- és müszakrend}

A foglalkoztatás szektorális jellege szerint öt csoportba sorolhatták magukat a megkérdezettek. Ezek alapján legtöbben a közszolgáltatás területén dolgoznak (35\%), ezt követően a szolgáltatási szektort alkotók csoportja a legnépesebb 
(31\%). Jelentősnek tekinthető a még az iparban (18\%), illetve a privát szektorban (11,5\%) munkát végzők aránya. Az előbbiekhez képest alacsony azok aránya, akik a mezőgazdasági szektorban dolgoznak..

A válaszadók 85\%-ának a jelenlegi munkavégzése eléri a heti 20 órát. Látható, hogy akik az általánosnak tekinthető heti 40 óránál kevesebbet dolgoznak, közülük a legtöbben azzal magyarázták ezt a jelenséget, hogy a munkaszerződésük ennél alacsonyabb munkaórára szól (35,3\%). Igen sokan (31,3\%), a minimális információ tartalommal bíró „egyéb” válaszlehetőséget jelölték meg. Egy jelentősnek tekinthető hányad az egészségi állapotát $(19,1 \%)$ jelölte meg magyarázó tényezőként, míg a negyedik legnépesebb csoportba azok tartoztak, akik GYES, illetve gyermeknevelés alatti munkavégzés lehetőségét kihasználva a gyermekgondozás mellett részmunkaidőben dolgoztak $(13,3 \%)^{3}$. A megfelelö álláskeresési stratégiák alkalmazása meghatározza a munkához jutatás sikerességét, és lerövidíthetik az álláskeresésre fordított időt. A hazai gyakorlat azt mutatja, hogy munkafelvétel esetén a munkaadók elsősorban saját közvetlen környezetükben keresik a megfelelő munkaeröt egy megüresedett álláshelyre (pl. saját ismeretségi körükben, vagy az adott vállalat dolgozónak ajánlására). Ennek eredményessége híján csak a következő körben hirdetik meg az állást nyilvánosan. Ehhez kapcsolódóan kíváncsiak voltunk arra, hogy a 2012-es nyíregyházi vizsgálatban részvevők hogyan jutottak jelenlegi állásukhoz. A válaszok alapján megállapíthatjuk, hogy a munkavállalók álláskeresési stratégiája és a említett munkaadók munkaerő választásának módja szinte teljesen egybeesik: a jelenleg foglalkoztatottak 33,5\%-a a családtól, barátoktól érkező információ segítségével jutott munkához, 29,6\% közvetlenül a munkáltatóhoz fordult, s 24\% álláshirdetésre jelentkezve tudott elhelyezkedni.

A megkérdezettek több mint háromnegyede dolgozott a jelenlegi munkahelye elött, vagyis igen kevesekre jellemző az egy munkahelyhez való kötődés. A nyíregyházi foglalkoztatottak többségének legalább két-három munkahelye volt már a jelenlegi előtt (56\%). Ez egybecseng azzal, hogy a helyi munkavállalási korú személyek közül minden negyedik közvetlenül szembesült már a munkanélküliséggel. A válaszadók közel negyedének 4-5, 7,5 \%-uknak 6-10 munkahelye volt 2012-ig (extrém esetek is előfordultak, 15-30 álláshellyel).

\footnotetext{
${ }^{3}$ Egy korábbi munkánkban részletesen vizsgáljuk a családtámogatások munkaerő-piaci hatásait. A tanulmány elérhető a Szabolcs-Szatmár-Beregi Szemle 47.évf. 4. számában 71-86.: R. Fedor és Fónai (2013): Kisgyermekes nők foglalkoztatási jellemzői és a családtámogatások igénybevétele.
} 


\section{Egyéb jövedelemszerző tevékenység}

2012-ben a nyíregyházi foglalkoztatottak mindössze 6,4\%-a végzett fö munkahelye mellett valamilyen egyéb jövedelemszerző tevékenységet. Ez jelentős visszaesést jelent a két, illetve négy évvel korábban mért adatokhoz képest, hiszen 2008-ban 10\%, 2010-ben pedig 13,4\% válaszolt hasonlóan. A további jövedelemszerző tevékenységet végzők alacsony aránya a fó állású jövedelmekkel való elégedettség tükrében igen meglepö, hiszen az esetek 35\%-ban azt tapasztaltuk, hogy a megkérdezettek ,elégedetlenek”, illetve ,teljesen elégedetlenek” jelenlegi fizetésükkel.

Nemek szerinti bontásban azt tapasztaljuk, hogy a férfiak körében magasabb a további jövedelmet is biztosító egyéb tevékenységet végzők aránya, mint a nőknél. Vélhetően ennek az az oka, hogy a nök számára kevésbé vonzók a másodlagos munkaerő-piac által kínált lehetőségek, „”, amit családi teendőik is akadályoznak.

A másodállás, mint jövedelem kiegészítő tevékenység leginkább a kvalifikáltabb társadalmi csoportok számára elérhető. Ez vélhetően a különböző iskolai végzettséggel rendelkezők másodlagos piacon eladható tudásának különbségeivel, és ezáltal a lehetőségekben megmutatkozó eltérésekkel magyarázható. A fizetéssel való elégedetlenségüket kifejezők számára megoldás lehet a másodlagos munka világában való fokozottabb részvétel . Vizsgálatunk eredményei alapján előző felvetésünk beigazolódott, azzal az kiegészítéssel, hogy a két legnagyobb arányú egyéb jövedelemszerző tevékenységet a fizetésükkel „elégedetlen- teljesen elégedetlen" és $a$, legelégedettebbek" csoportjából került ki.

\begin{tabular}{|cccccccc|}
\hline & $\begin{array}{c}\text { Nem } \\
\text { befejezett } \\
\text { általános } \\
\text { iskola }\end{array}$ & $\begin{array}{c}\text { 8 általános } \\
\text { iskola }\end{array}$ & $\begin{array}{c}\text { Szak } \\
\text { munkás- } \\
\text { képző }\end{array}$ & $\begin{array}{c}\text { Szak } \\
\text { közép- } \\
\text { iskola }\end{array}$ & $\begin{array}{c}\text { Gimná- } \\
\text { zium }\end{array}$ & Főiskola & Egyetem \\
\hline $\mathbf{2 0 0 8}$ & 0,0 & 2,0 & 18,8 & 21,8 & 11,9 & 29,7 & 14,9 \\
$\mathbf{2 0 1 0}$ & 0,0 & 1,3 & 18,5 & 18,5 & 13,2 & 31,6 & 17,1 \\
$\mathbf{2 0 1 2}$ & 0,0 & 0,0 & 15,2 & 21,5 & 19,0 & 29,1 & 15,2 \\
\hline
\end{tabular}

sig, 0,000

1. számú táblázat. Egyéb jövedelemszerző tevékenységek aránya az iskolai végzettség tükrében Nyíregyházán (\%).

Forrás: Háztartáspanel 2008; 2010, 2012. 
Az iskolai végzettség függvényében vizsgálva a másodállással rendelkezők öszszetételét megállapíthatjuk, hogy a vizsgálat három időszakában jelentős változást nem tapasztalhatunk. Az iskolai végzettség emelkedésével a másodlagos munkaerőpiac által kínált lehetőségek nőnek.

\section{Munkanélküliség}

2012-ben a munkanélküliségi ráta országos értéke 10,9\%-os volt, hasonlóan az egy évvel korábbihoz. A munkanélküliek számának csökkenése a gazdaságilag kedvezőtlenebb háttérrel rendelkező régióban megindult (pl. Észak-Alföld), míg a jobb helyzetü régiókban növekedett. Ennek hatására az évtizedek óta fennálló területi különbségek mérséklődtek. Azonban a munkanélküliséggel leginkább (Észak-Magyarország, 16,6\%) és legkevésbé érintett (Nyugat-Dunántúl, 7,4\%) régiók közötti különbség ma is számottevő 9,2\% (KSH 2012).

Az érintett évben a munkanélküliek $45 \%$-a nő, $55 \%$-a férfi volt. Az iskolai végzettség munkanélküliséggel szembeni védelmező hatása továbbra is jelentős. A munkanélküliek legnagyobb csoportja legfeljebb nyolc osztályt (28,9\%), illetve szakmunkásképzőt és szakiskolát végzett (32,3\%). Az érettségivel rendelkezők állástalanokon belüli aránya $29 \%$, a diplomásoké $10 \%$. E csoportban, tehát a felsőfokú végzettséggel rendelkezők körében az utóbbi évek mindegyikében nőtt a munkanélküliek száma (KSH 2012).

Szabolcs-Szatmár-Bereg megyében 16,2\%-os volt a munkanélküliségi ráta 2012-ben. Ez közel 2\%-kal kedvezőbb a 2010. évihez, és 1,4\%-kal a 2008. évihez képest. A csökkenés ellenére a megye helyzete nem javult az országos átlaghoz viszonyítva.

Nyíregyházi vizsgálatunkban azt tapasztaltuk, hogy a megkérdezettek negyede eddigi élete során már megtapasztalta a munkanélküliséget. Az álláskeresőkön belül a legnagyobb súllyal szereplő csoport egy és két év közötti munka nélkül eltöltött időtartamról számolt be. A munkanélkülieken belül a nők aránya $53 \%$, a férfiaké $47 \%$ volt.

Ahogyan azt említettük, a megszerzett iskolai végzettség jelentősen meghatározza az elhelyezkedési lehetőségeket. Vizsgálatunk eredményei, hasonlóan az országos munkaerő-felmérés következtetéseihez, visszaigazolják az iskolai végzettség és a munkanélküliség közötti kapcsolatot. Az állástalanok legnagyobb csoportját a legfeljebb szakmunkás bizonyítvánnyal rendelkezők adják (38\%), őket követik a szakközépiskolában érettségizettek (20,4\%), a gimnáziumban $(17,6 \%)$ végzettek és a föiskolai diplomával rendelkezők (18,8\%). A munkanél- 
küliséggel szemben a legnagyobb védettséget az egyetemi diploma adja, a diplomások mindössze 4,9\% szembesült a munkanélküliséggel eddigi élete során.

\section{Összefoglalás}

Elemző munkánkban Nyíregyháza város lakói gazdasági aktivitásának jellemzőit térképeztük fel, a 2008., 2010. és 2012. évi Háztartáspanel felvételek adatai alapján. Tanulmányunkban elsősorban a helyi foglalkoztatási, illetve a munkanélküliségi tendenciák bemutatását vállaltuk. Összehasonlító vizsgálatunkban arra törekedtünk, hogy a helyi jellemzőket megyei és regionális vonatkozásban is értelmezzük. Összességében megállapíthatjuk, hogy a nyíregyháziak foglalkoztatási szintje kedvezően alakult 2008-hoz és 2010-hez képest is. A foglalkoztatás bővülése nem volt egyenletes a nők és a férfiak tekintetében, vizsgálatunk szerint utóbbiak helyzete javult nagyobb mértékben. Az iskolai végzettség függvényében azt tapasztaltuk, hogy az elhelyezkedési lehetőségek továbbra is a kvalifikáltabb társadalmi csoportoknak kedveznek, annak ellenére, hogy az egyetemi diplomával rendelkezők körében 2012-ben csökkent a foglalkoztatottak aránya. Nyíregyházi vizsgálatunkban azt tapasztaltuk, hogy a megkérdezettek negyedének volt már tapasztalata a munkanélküliségről eddigi élete során. Az érintettek jelentős hányadát a legfeljebb szakmunkás bizonyítvánnyal rendelkezők alkották, míg az egyetemi diplomával rendelkezők részesedése nagyon alacsony, azaz a magasabb iskolai végzettség a mai napig egyfajta védettséget jelent a munkanélküliséggel szemben Mindemellett a gazdasági aktivitás jellemzői - az életminőség, ezen belül is az szubjektív egészségi állapot - az önbecsülés egyik fontos mutatója (R. Fedor 2012, Jávorné Erdei et al. 2014).

\section{Felhasznált irodalom}

1. Altorjai Szilvia-Róbert Péter (2006): Munkaorientáció, emberi tőkemegtérülés. In: Kolosi Tamás-Tóth István György - Vukovich György (szerk.): Társadalmi Riport. TÁRKI, Budapest, 314-333.

2. Fábián Gergely (2008): A gazdasági aktivitás jellemzői (munkavégzéssel kapcsolatos jellemzők) http://odin.de-efk.hu/content/view/1516/277/ letöltve: 2010 . szeptember 28.

3. Fábián Gergely (2010): A gazdasági aktivitás jellemzői. Kézirat.

4. Ferge Zsuzsa (2010): A Munkaerő-felmérés 15 évének tanulságai a gyermekes családok szempontjából. MTA GYEP Iroda. In. Esély 2010/6. 
5. Jávorné Erdei, R. ${ }^{1}$, Gyulai, A ${ }^{1}$, Rusinné Fedor, A. ${ }^{2}$, Takács, P (2014).: Quality of life andcommunity activities In.: Euroregional Journal of SocioEconomic Analysis. Year II, Issue 1, July 38-45.

6. R. Fedor Anita (2012): A gazdasági aktivitás lokális jellemzői. Nők és férfiak a „munka piacán”. In: Fábián Gergely - Patyán László - Huszti Éva (szerk.): Életminőség Nyíregyházán. Acta Medicinae et Sociologica folyóirat különszáma, Nyíregyháza, 83-98.

7. R. Fedor Anita - Fónai Mihály (2013): Kisgyermekes nők foglalkoztatási jellemzői és a családtámogatások igénybevétele. In: Szabolcs-SzatmárBeregi Szemle 47.évf. 4. szám. 71-86.

8. Rosen, S. (1998): Emberi tőke. In: Lengyel György - Szántó Zoltán (szerk.): Tőkefajták: a társadalmi és kulturális erőforrások szociológiája. Budapesti Közgazdaságtudományi Egyetem, Aula Kiadó, Budapest, 71-100.

9. Scharle Ágota (2008): Foglalkoztatás, intézményrendszer és foglalkoztatáspolitika In: Kolosi Tamás - Tóth István György (szerk.): Társadalmi Riport. TÁRKI, Budapest, 257-289.

10. Varga Júlia (1998): Oktatás-gazdaságtan. Közgazdasági Szemle Alapítvány, Budapest.

\section{Felhasznált statisztikai kiadványok}

1. A foglalkoztatás és a munkanélküliség regionális különbségei, 2012. KSH. 2013. július

2. Munkaerő-piaci folyamatok, 2012. I-III. negyedév. KSH.

3. Statisztikai tájékoztató Szabolcs-Szatmár-Bereg megye, 2012/2.

4. Társadalmi helyzetkép 2010. KSH.

R. Fedor Anita: föiskolai adjunktus

Debreceni Egyetem Egészségügyi Kar, 4400 Nyíregyháza, Sóstói u. 2-4.

Jávorné Erdei Renáta: gyakorlati oktató

Debreceni Egyetem Egészségügyi Kar, 4400 Nyíregyháza, Sóstói u. 2-4. 
